\title{
Experimental Study on Compressive Strength of Glass Fibre Reinforced Concrete and Partial Replacement of Cement with Flyash Research
}

\author{
Ms. Reshma T.V
}

\begin{abstract}
Glass fibre reinforced concrete is recent development in the field of concrete technology. Concrete being the most important and widely used material is called upon to possess very high strength and sufficient workability properties. The concrete has more desirable properties like High compressive strength, stiffness, durability. At the same time concrete is brittle and weak in tension. To improve the concrete properties, the system was named glass- fibre reinforced concrete view the alkali resistance glass fibre is used.

In thefirst part of experimental investigation, the glass fibre has been used to study the effect on compressive strength on M15, M20 \& M25 grade of concrete for different \% of glass fibreie., $0 \%, 3 \%, 5 \%, 7 \%$ by weight of aggregates.

And in today's world the main emphasis is on green and sustainable development. Presently large amount of fly ash is generated in thermal power plants as a waste material with an improper impact on environment and humans. Fly ash is difficult to decompose, so using fly ash is a major step towards sustainable development. Also, Cement industry is one of the major contributors to pollution by releasing carbon dioxide. So, by partially replacing cement with pozzolanic material such as fly ash, the cement industry can serve both the purposes of meeting the demands of construction industry and at the same time providing a green and clean environment. This research workincludes second part whichinvestigates the behavior of concrete and optimum percentage while replacing fly ash in different proportions. The cement has been replaced accordingly in the range of $0 \%, 18 \%, 20 \% \& 22 \%$ by weight of cement of M25 grade concrete. Concrete mixtures were produced, tested and compared in terms of compressive strength, as an alternative to traditional concrete.
\end{abstract}

Index Terms - Compressive strength, Fly ash, Glass Fibre Reinforced Concrete, Silica fume.

\section{INTRODUCTION}

Concrete is having high compressive strength with limitations of Brittle, Less tensile strength, Low Impact resistance, Less fatigue resistance and poor ductility. The failure of concrete occurs because of the pores present in it. This can be minimized by using thin fibres called glass fibres. Glass fibre reinforced concrete is one of the most versatile building materials for architects and engineers.

It is mainly used for the construction of thin, light-weight exterior building façade and architectural pre-fabricated cladding panels. It primarily composed of cement, sand, glass fibre, coarse aggregate and water in construction.

Fly ash is a predominantly inorganic residue obtained from the flue gases of furnaces at pulverized coal powerplants.

Ms. Reshma T V, School of Civil Engineering, REVA University, Yelahanka, Bengaluru, Karnataka, India
When coal is burnt in pulverized coal boilers, the minerals, entrained in the coal, are thermally transformed into chemical species that are reactive or could be chemically activated, for example by the addition of calcium hydroxide.The finely divided glass phase, the predominant phase in fly ash a siliceous and aluminous material that in itself possesses little or no cementitious value but will, in finely divided form and in the presence of moisture, chemically react with calcium hydroxide at ordinary temperatures to form compounds possessing cementitious properties.

\section{METHODOLOGY}

In this experimental investigation, the glass fibres are used to study the effects on compressive strength test on M15, M20 \& M25 grade of concrete for different \% of glass fibreie., $0 \%, 3 \%, 5 \%, 7 \%$ by weight of aggregates.

Using fly ash in construction of concrete as an admixture improves the properties. By replacing the cement with fly ash accordingly in the range of $18 \%, 20 \%, 22 \%$ by weight of cement in M25 grade of concrete.

- To determine the optimum percentage of fly ash for M25 grade concrete based on Compressive strength, to test with four different fly ash dosages of $0 \%$, $18 \%, 20 \%, 22 \%$.

- To determine the compressive behaviour of glass fibre-reinforced concrete and fly ash concrete and compared against the conventional concrete of the same concrete grades.

\section{MATERIALS SPECIFICATION}

3.1 Cement:Ordinary Portland cement of 43 grade, conforming to recommendations stated in IS 4031(1999) is used. The normal consistency, specific gravity and initial setting time of cement was 33\%, 3.10 and 47 minutes respectively.

3.2 Fine Aggregate: M Sand locally available to us was used as fine aggregate. The test procedures as mentioned in IS-383(1970) were followed to determine the physical properties of fine aggregate.

3.3 Coarse Aggregate:Single sized crushed stone aggregates ranging $20 \mathrm{~mm}$ to $12 \mathrm{~mm}$ (20 $\mathrm{mm}$ size) were used in respective proportions in concrete mixes. The aggregates were tested in accordance to IS-383: (1970).

3.4 Water:As per recommendation of IS: 456 (2000), the water to be used for mixing and curing of concrete should be free from deleterious materials. Therefore, potable water was used with a constant w/c as 0.5 in the present study. 
Experimental Study on Compressive Strength of Glass Fibre Reinforced Concrete and Partial Replacement of Cement with Flyash Research

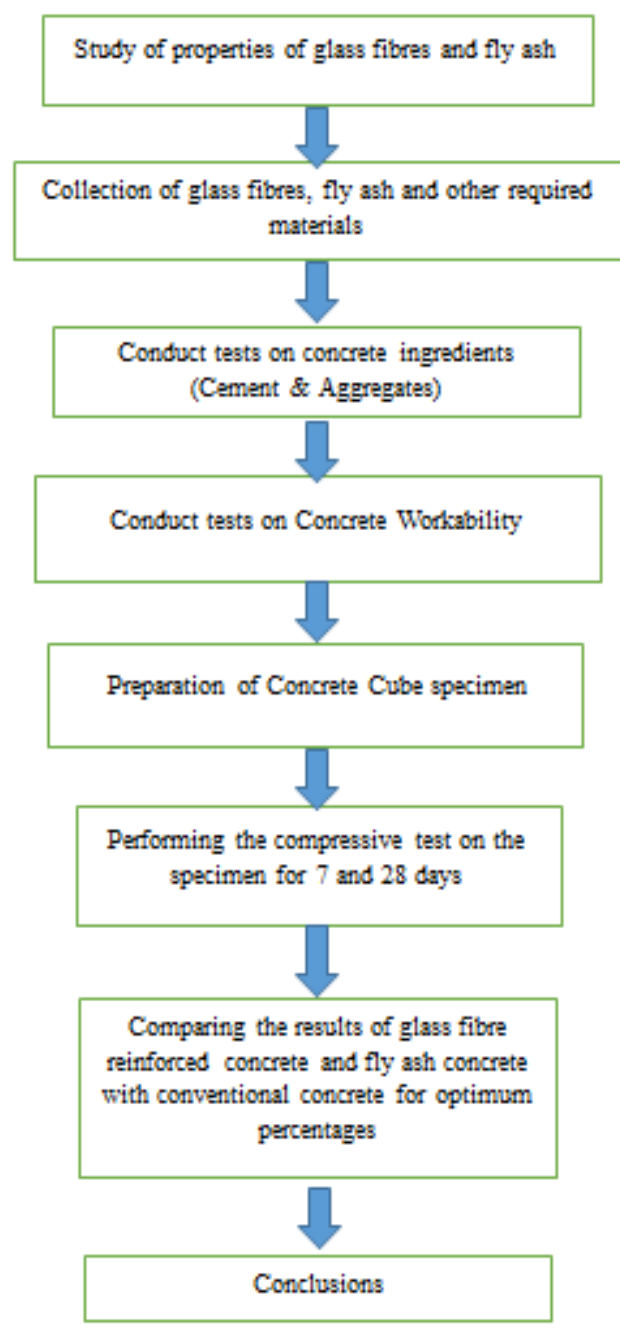

Fig 1 Flow chart of methodology

3.5 Glass fibres:Cem-Fil Anti-Crack, HD-12mm, Alkali Resistant glass fibres were used throughout the experimental work. From the micro to the macro fibre range, these fibres control the cracking processes that can take place during the life-span of concrete.

\section{RESULTS AND DISCUSSION}

Table-I: Test on aggregates

\begin{tabular}{|c|c|c|c|}
\hline Materials & $\begin{array}{c}\text { Specific } \\
\text { Gravity }\end{array}$ & $\begin{array}{c}\text { Water } \\
\text { Absorption }\end{array}$ & $\begin{array}{c}\text { Fineness } \\
\text { modulus }\end{array}$ \\
\hline $\begin{array}{c}\text { Fine } \\
\text { aggregate }\end{array}$ & 2.63 & $3.09 \%$ & 2.74 \\
\hline $\begin{array}{c}\text { Coarse } \\
\text { aggregate }\end{array}$ & 2.65 & $2.33 \%$ & 6.48 \\
\hline
\end{tabular}

Table-II: Average compressive strength of glass fibre reinforced concrete in $\mathrm{N} / \mathrm{mm}^{2}$ after 7 days of curing.

\begin{tabular}{|c|c|c|c|c|}
\hline \multirow{2}{*}{$\begin{array}{c}\text { Grade of } \\
\text { Concrete }\end{array}$} & $\begin{array}{c}\text { Conventional } \\
\text { concrete or 0 } \\
\%\end{array}$ & \multicolumn{3}{|c|}{$\begin{array}{c}\text { Glass fibre reinforced } \\
\text { concrete }\end{array}$} \\
\cline { 3 - 5 } & 6.58 & $3 \%$ & $5 \%$ & $7 \%$ \\
\hline M15 & 13.8 & 15.32 & 10.65 & 11.13 \\
\hline M20 & 16.31 & 18.96 & 19.10 & 16.11 \\
\hline M25 & 16.63 \\
\hline
\end{tabular}

Table-III: Average compressive strength of glass fibre reinforced concrete in $\mathrm{N} / \mathrm{mm}^{2}$ after 28 days of curing.

\begin{tabular}{|c|c|c|c|c|}
\hline \multirow{2}{*}{$\begin{array}{c}\text { Grade of } \\
\text { Concrete }\end{array}$} & $\begin{array}{c}\text { Conventional } \\
\text { concrete or } 0 \\
\%\end{array}$ & \multicolumn{3}{|c|}{$\begin{array}{c}\text { Glass fibre reinforced } \\
\text { concrete }\end{array}$} \\
\cline { 3 - 5 } & 15.77 & $3 \%$ & $5 \%$ & $7 \%$ \\
\hline M15 & 19.85 & 24.54 & 21.35 & 22.13 \\
\hline M20 & 24.4 & 28.41 & 29.25 & 30.13 \\
\hline M25 & &
\end{tabular}

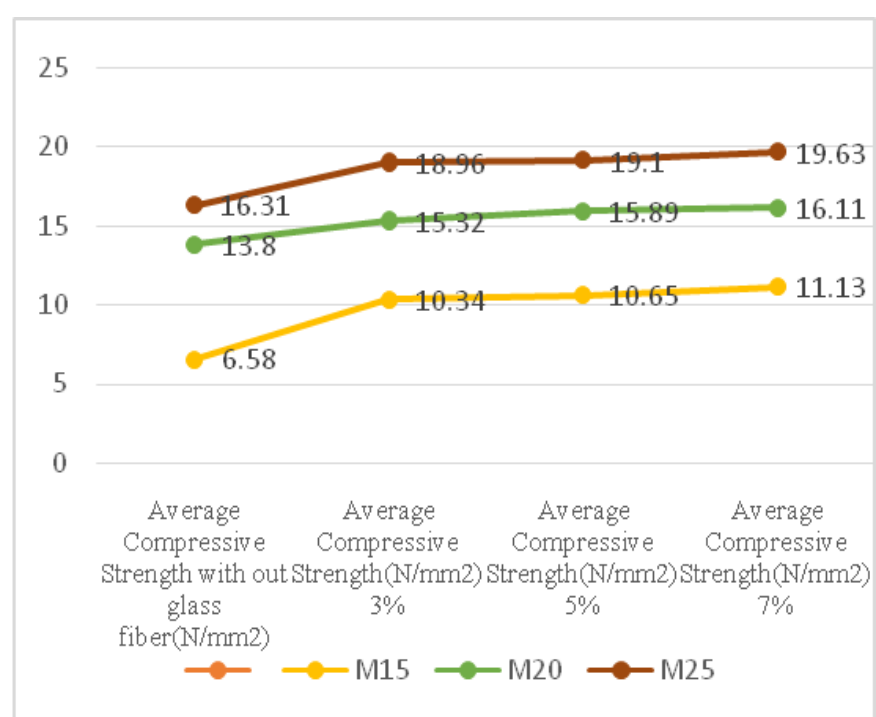

Fig. 2 : Percentage reinforcementv/s Average compressive strength of glass fibre reinforced concrete in $\mathrm{N} / \mathrm{mm}^{2}$ after 7 days of curing

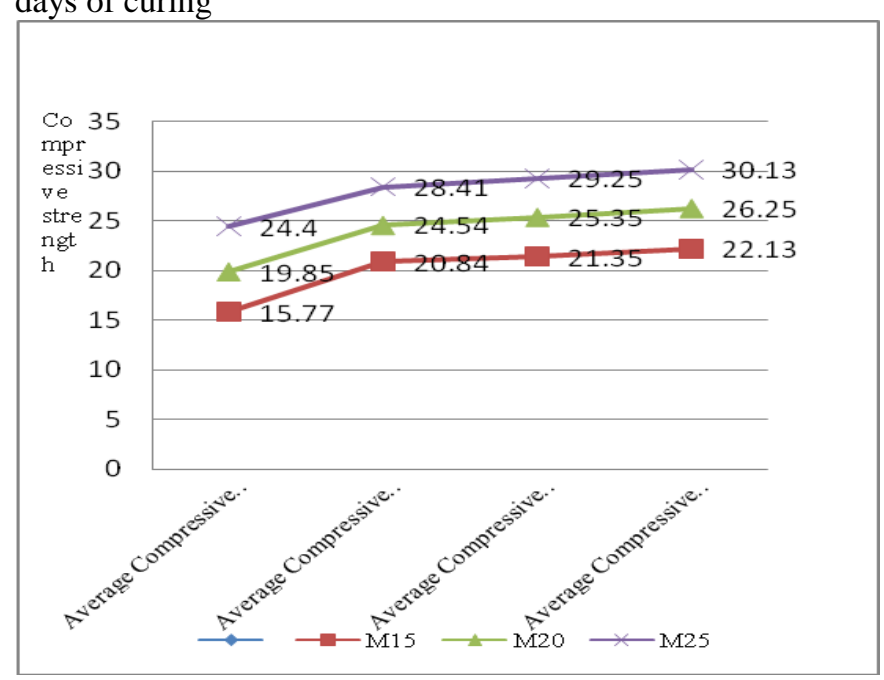

Fig. 3 : Percentage reinforcement v/s Average compressive strength of glass fibre reinforced concrete in $\mathrm{N} / \mathrm{mm}^{2}$ after 28 days ofcuring.

Fly ash concrete samples

- Sample 1: $18 \%$ fly ash and $82 \%$ cement

- Sample 2:20\% fly ash and 80\% cement

- Sample 3:22\% fly ash and 82\% cement 
Table-IV: Average compressive strength of fly ash concrete in $\mathrm{N} / \mathrm{mm}^{2}$ after 7 days of curing.

\begin{tabular}{|c|c|c|c|c|}
\hline \multirow{2}{*}{$\begin{array}{c}\text { Grade of } \\
\text { Concrete }\end{array}$} & $\begin{array}{c}\text { Conventional } \\
\text { concrete or 0 } \\
\%\end{array}$ & \multicolumn{3}{|c|}{$\begin{array}{c}\text { Percentage replacement of } \\
\text { cement with fly ash }\end{array}$} \\
\cline { 2 - 5 } & 15.8 & $18 \%$ & $20 \%$ & $22 \%$ \\
\hline \multirow{3}{*}{ M25 } & 16.67 & 17.14 & 17.02 & 17.62 \\
\cline { 2 - 5 } & 16.31 & 17.36 & 17.33 & 17.03 \\
\hline Average & 16.26 & 17.04 & 17.067 & 17.30 \\
\hline
\end{tabular}

Table-V: Average compressive strength of fly ash concrete in $\mathrm{N} / \mathrm{mm}^{2}$ after 28 days of curing.

\begin{tabular}{|c|c|c|c|c|}
\hline \multirow{2}{*}{} & $\begin{array}{c}\text { Conventional } \\
\text { concrete or 0 } \\
\%\end{array}$ & \multicolumn{3}{|c|}{$\begin{array}{c}\text { Percentage replacement of } \\
\text { cement with fly ash }\end{array}$} \\
\cline { 2 - 5 } & 25.67 & 30.07 & 31.01 & 31.05 \\
\hline \multirow{3}{*}{ M25 } & 26.8 & 29.85 & 30.03 & 31.02 \\
\cline { 2 - 5 } & 24.4 & 30.38 & 30.45 & 30.09 \\
\hline Average & 25.63 & 30.09 & 30.49 & 30.72 \\
\hline
\end{tabular}

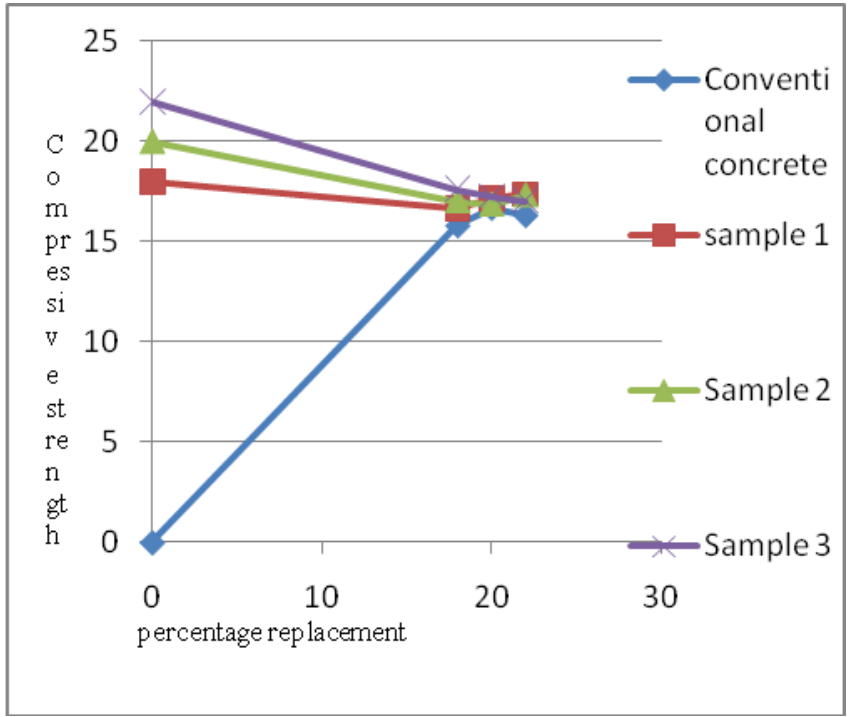

Fig 4:Average compressive strength of fly ash concrete in $\mathrm{N} / \mathrm{mm}^{2} \mathrm{v} / \mathrm{s}$ percentage replacement after 7 days of curing

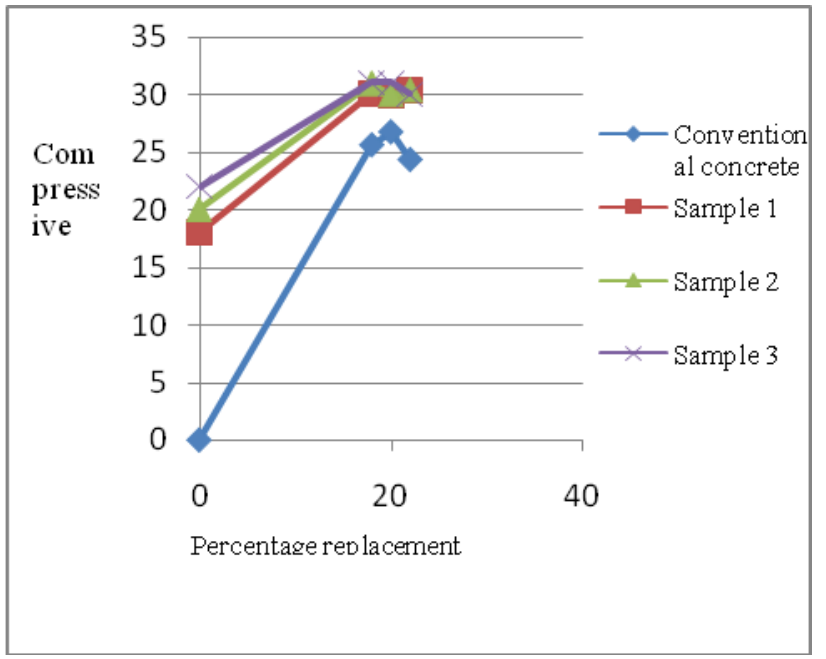

Fig 5:Average compressive strength of fly ash concrete in $\mathrm{N} / \mathrm{mm}^{2} \mathrm{v} / \mathrm{s}$ percentage replacement after 28 days of curing
The above tables and graph represents the variation of compressive strength of concrete with different percentages of glass fibre reinforcement and percentage replacement of cement with fly ash.

As the percentage of glass fibre increases, the compressive strength also increases. The reinforcement of glass fibre is effective in reducing the costs of material and results in good strength and resistance to cracks, impact or shocks by giving life for the structure.

The partial replacement of fly ash with cement gives considerable increment in the compressive strength of concrete. Due to the fineness of the fly ash, it possesses same as cementitious properties which results in economic construction. This selection of percentage for the experiment is based on research works and Indian Standards.

\section{CONCLUSION}

- Eco-friendly and economical compared to conventional mixed concrete.

- The glass fibre reinforced concrete showed almost 20 to $30 \%$ increase in compressive strength. The percentage increase in strength for higher grades of concrete is high

- A reduction in bleeding improves the surface integrity of the concrete, improves its homogeneity and reduces the probability of cracks.

- Glass fibre reinforced concrete withstands higher temperatures during fire accidents compared to normal concrete.

- Use of alkali resistant material like glass fibre improves the quality of work than the conventional concrete.

- Fly ash concrete gives improved workability with less water-cement ratio

- Both concrete results in reduction of shrinkage during curing.

\section{REFERENCES}

[1] A. UpendraVarma et al Int. Journal of Engineering Research and Applications (ISSN: 2248-9622, Vol. 3, Issue 5, Sep-Oct 2013, pp.1914-1918)

[2] Chandramouli.K, Srinivasa.R.P, Pannirselvam.N, Sekhar.T (2010) "Strength Properties of Glass Fibre Concrete" ARPN Journal of Engineering and Applied Sciences, vol-5, No-4, April 2010.

[3] Experimental Study on Properties of Glass Fibre Reinforced Concrete International Journal of Engineering Trends and Technology (IJETT)

[4] IS:4031 (PART-6)-1988 "Methods of physical tests for hydraulic cement, Determination of compressive strength of hydraulic cement (other than masonry cement) by Bureau of Indian Standards".

[5] ] Prof. Jayesh Kumar Petrosa, Rd. L. B. Zale, Rd. F.S. Umrika, "Experimental Investigation on Partial Replacement of Cement With Fly Ash in Design Mix Concrete", International Journal of Advanced Engineering \& Technology, Volume-03/Issue 04/ Oct. Dec., 2012/ 126-129.

[6] M. Islam, S. Islam (2012), Prospect of Green Concrete Production by Using Boropukuriya Fly Ash, Conf. Proceedings of 1st International Conference on Advances in Civil Engineering 2012 (ICACE 2012), CUET, Chittagong, Bangladesh.

[7] Marsh, B.K., Day, R.L. and Bonner, D.G. (1985). Pore Structure Characteristics Affecting the Permeability of Cement Paste Containing Fly Ash. Cement Concrete Res., 15 (6):1027-1038.

[8] P.Sreejith, "Glass Fibre Reinforced Concrete a Complete Study", 2010 Retrieved from https://sreejithknols.wordpress.com/article/glass-fibre-reinforced -concrete-gfrc-27d4pai9ji3et-22/ 
[9] P.R.Wankhede, V.A.Fulari, "Effect of Fly Ash on Properties of Concrete", International Journal of Emerging Technology And Advanced Engineering, Volume 4, Issue 7 July 2014, Page no 284.

[10] Tomas U.GanironJr ",Analysis of Fly Ash Cement Concrete for Road Construction", International Journal of Advanced Science And Technology, Volume 60, page no 33

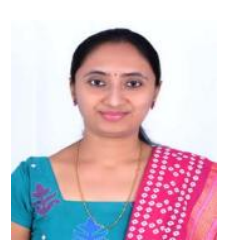

Author:Ms. Reshma T V, Assistant Professor, School of Civil Engineering, REVA University, Bengaluru holds M.Tech degree in Structural Engineering' from Vishweshwaraya Technological University and B. E. degree in Civil Engineering from VTU . I havemore than 3 years of experience in teaching and research. My research interests are in the areas of Concrete technology, Earthquake resistant structures and Optimization techniques. My research paper has been accepted for ICONS 2018 which is going to be held in December 2018 at IIT Madras. 